\title{
COVID-19 and Human Immune System Responses
}

\author{
Sylvia Smart* \\ Master of Health Science, Sydney, NSW Australia \\ *Corresponding author: Sylvia Smart, Master of Health Science, Sydney, NSW Australia
}

\begin{tabular}{|c|c|}
\hline ARTICLE INFO & ABSTRACT \\
\hline & $\begin{array}{l}\text { Citation: Sylvia Smart. COVID-19 and Human Immune System Responses. Biomed J Sci } \\
\text { \& Tech Res 41(4)-2022. BJSTR. MS.ID.006633. }\end{array}$ \\
\hline Published: February 03, 2022 & \\
\hline
\end{tabular}

\section{Introduction}

Coronavirus disease (COVID-19) is caused by SARS-CoV, a highly infectious virus that has become a global health challenge since 2020 (Lai, et al. [1]). The virus effects on individual immune can be mild to moderate and severe to some. Immunity is the ability of organisms to protect the body from attacks from particular toxin infections (Yazdanpanah, et al. [2]). The emergence of the SARS-CoV into the human body affects the immunity system. Usually, the body immunity can detect foreign organisms and fight back by releasing antibodies that protect the entry (West, et al. [3]). However, Covid-19 emergence of Covid-19 has led to many research pieces to determine how the immune system and disease correspond. COVID-19 directly or indirectly affects the immune system through the hype inflammatory immune response in patients with underlying conditions. The virus leads to severe Acute Respiratory distress symptoms and organ failure (Abu-Izneid, et al. [4]). SARSCoV-2 enters the cell through (ACE-2) that is detected by Toll-like receptor 7 (TLR7) (Ahmadpoor [5]). When the Coronavirus attacks the body, the immune system tries to fight through cytokine storms that have adverse effects and even cause death. The presence of two domains that is S1 and S2, in glycoprotein is responsible for attachment, invasion, and entry to the body (Barcena, et al. [6]). The SARS-CoV interacts with the host cell through the ACE2 and another host called protease TMPRSS2 (Davidson, et al. [7]). The interaction of coronavirus and host cells causes the non-structural proteins that utilize the virulence factors Kumar, et al. [8].

The increased rate of enzymes production within the kidneys, liver, and heart in patients suffering from anemia induces an underlying expression of tissues of the ACE2 receptor (Kuppusamy, et al. [9]). The entry mechanism of both SARS-CoV and SARS-CoV2 are almost similar, and the ACE2 receptor binds the glycoprotein with the virus (Yang, et al. [10]). The Toll-Like Receptor-7 senses the interaction and binding responsible for producing inflammatory cytokines (Dyavar, et al. [11]). The secretion of hyper-inflammatory cytokines in various body parts, such as the lungs, causes acute respiratory distress (Lin, et al. [12]). The ACE2 factors are present in some organs, such as the kidneys, the heart cells, epithelial lung cells, and the liver (Deshmukh, et al. [13]). When Coronavirus enters the body, it interferes with multiple receptors that sense the virus, blocking the Ribonucleic acid (RNA). The activation of TLR7 in endosomes secretes alpha-interferon that contributes to the production of antibodies and antigen B specific (Ahmadpoor, et al. [5]). The above action mechanism depends on the adaptive immune response that dominates virus infections and dictates recovery. The effects of Covid-19 on the immune system vary from the individual; some response of antibodies released by white blood cells determines the strength to fight the virus. The human body contains white blood cells that are the key player in maintaining the immune system (da Silveira, et al. [14]). The function of white blood cells is to block entry of harmful toxicity and detect any cell changes because it travels throughout the body in blood cells (Farahinia, et al. [15]).

According to (Wiig [16]) body exchange fluid and cells between the lymphatic and blood vessels to form the lymphatic system. Lymph nodes encounter antigens where foreign organisms, 
immune cells, and lymphatic vessels enter the nodes (Leong, et al. [17]). The immune cells, foreign antigens, and lymph vessels are transmitted throughout the bloodstream by the blood vessels surveying foreign antigens (Hickey, et al. [18]). The immune cells and the lymphatic vessels then drift back to lymph nodes, where they fight foreign antigens by stimulating antibodies (Chowdhury, et al. [19]). The immune system is ideal for fighting foreign antigens because of its natural body defense mechanism. The entry of the COVID-19 virus slowed down the body's immunity because the virus is highly inflammatory, and it is the first time it attacks the body; hence, the virus becomes fatal and is likely to cause illness. The effects of the Coronavirus vary from individuals depending on the strength of immunity, the aged, children, and those with underlying conditions such as high blood pressure, pneumonia, and respiratory problems. Since the emergence of COVID-19, the appropriate treatment has not been determined; hence, many researchers have opted for natural cure and prevention measures to help reduce the effects of the virus. Nutrients and supplements perpetuate the healthy immunity from individual dietary patterns (Trujillo-Mayol, et al. [20]).

The individual is responsible for host metabolic status such as diet, lifestyle, and nutrition with the surrounding conditions fosters the clinical and recovery manifestation. Based on diet, there are specific nutrients that individuals should consider taking in plenty to help boost body immunity, such as Vitamins, iron, and other adequate nutrients status (Gasmi, et al. [21]). The Coronavirus less affects strong immunity (Brodin [22]). Proper nutrition and hydration are vital supplements during COVID -19. Eating well balanced makes the body healthier and ensures stronger immune systems that lower the risk of the infectious virus. Thus, individuals are encouraged to eat various fresh and unprocessed foods daily to get adequate vitamins, minerals, dietary fibre, protein and antioxidants that the body requires (WHO [23]). In addition, taking plenty of water is also critical in enabling the body to stay hydrated and speeds upmetabolic activities that require more energy. The consumption of a balanced diet and environmental toxins interact with the host (García Bayona, et al. [24]). The Microbiota speeds up the interaction between the host and the linings to various organs such as lungs, liver, heart etc. The barrier lining creates integrates antimicrobial peptides that protect the internal environment from microbial translocation and secretion of protective mucous. The other natural prevention of COVID-19 is regular exercise enhances the body's physical fitness and eradicates the developing diseases that might speed up the virus infections (Matricardi, et al. [25]). COVID-19 is mild when it interacts with ill patients having underlying conditions; hence, physical exercise helps regulate blood sugar body pressure and enhance metabolic functions.

\section{References}

1. Lai CC, Shih TP, Ko WC, Tang HJ, Hsueh PR, et al. (2020) Severe acute respiratory syndrome coronavirus 2 (SARS-CoV-2) and coronavirus disease-2019 (COVID-19): The epidemic and the challenges. International Journal of Antimicrobial Agents 55(3): 105924.

2. Yazdanpanah F, Hamblin MR, Rezaei N (2020) The immune system and COVID-19: Friend or foe? Life Sciences 256: 117900.

3. West R, Kobokovich A, Connell N, Gronvall GK (2021) COVID-19 antibody tests: a valuable public health tool with limited relevance to individuals. Trends in Microbiology 29(3): 214-223.

4. Abu Izneid T, AlHajri N, Ibrahim AM, Javed MN, Salem KM, et al. (2021) Micro-RNAs in the regulation of immune response against SARS CoV-2 and other viral infections. Journal of advanced research 30: 133-145.

5. Ahmadpoor P, Rostaing L (2020) Why the immune system fails to mount an adaptive immune response to a Covid-19 infection. Transplant International 33(7): 824-825.

6. Barcena M, Barnes CO, Beck M, Bjorkman PJ, Canard B, et al. (2021) Structural biology in the fight against COVID-19. Nature Structural and Molecular Biology 28(1): 2-8.

7. Davidson AM, Wysocki J, Batlle D (2020) Interaction of SARS-CoV-2 and other Coronavirus with ACE (angiotensin-converting enzyme)-2 as their main receptor: Therapeutic implications. Hypertension 76(5): 13391349.

8. Kumar A, Prasoon P, Kumari C, Pareek V, Faiq MA, et al. (2021) SARSCoV-2-specific virulence factors in COVID-19. Journal of medical virology 93(3): 1343-1350.

9. Kuppusamy M, Wankhar W, Gurugubelli KR, Mahadevappa VH, Lepcha $\mathrm{L}$, et al. (2021) Angiotensin-converting enzyme 2 (ACE2): COVID 19 gate way to COVID-19 and Human Immune System Responses 8 multiple organ failure syndromes. Respiratory Physiology \& Neurobiology 283: 103548.

10. Yang J, Petitjean SJ, Koehler M, Zhang Q, Dumitru AC, et al. (2020) Molecular interaction and inhibition of SARS-CoV-2 binding to the ACE2 receptor. Nature Communications 11(1): 1-10.

11. Dyavar SR, Singh R, Emani R, Pawar GP, Chaudhari VD, et al. (2021) Role of toll-like receptor $7 / 8$ pathways in regulation of interferon response and inflammatory mediators during SARS-CoV2 infection and potential therapeutic options. Biomedicine \& Pharmacotherapy 141: 111794.

12. Lin SH, Zhao YS, Zhou DX, Zhou FC, Xu F, et al. (2020) Coronavirus disease 2019 (COVID-19): cytokine storms, hyper-inflammatory phenotypes, and acute respiratory distress syndrome. Genes \& Diseases 7(4): 520527.

13. Deshmukh V, Motwani R, Kumar A, Kumari C, Raza, K, et al. (2021) Histopathological observations in COVID-19: a systematic review. Journal of Clinical Pathology 74(2): 76-83.

14. Da Silveira MP, Da Silva Fagundes KK, Bizuti MR, Starck É, Rossi RC, et al. (2021) Physical exercise as a tool to help the immune system against COVID-19: an integrative review of the current literature. Clinical and Experimental Medicine 21(1): 15-28.

15. Farahinia A, Zhang WJ, Badea I (2020) Circulating Tumor Cell Separation of Blood Cells and Sorting in novel Microfluidic approaches: a review. Preprints.

16. Wiig H (2021) As for blood vessels, the answer regarding lymphatics is often NO. Acta Physiologica 232(4): e13697. 
17. Leong SP, Pissas A, Scarato M, Gallon F, Pissas MH, et al. (2021) The lymphatic system and sentinel lymph nodes: conduit for cancer metastasis. Clinical \& Experimental Metastasis, p. 1-19.

18. Hickey MJ, Norman MU (2020) Immune system imaging. In Imaging from Cells to Animals In Vivo. CRC Press, pp. 279-294.

19. Chowdhury MA, Hossain N, Kashem MA, Shahid MA, Alam A, et al. (2020) Immune response in COVID-19: A review. Journal of Infection and Public Health 13(11): 1619-1629.

20. Trujillo Mayol I, Guerra Valle M, Casas Forero N, Sobral MMC, Viegas O, et al. (2021) Western dietary pattern antioxidant intakes and oxidative stress: importance during the SARS-CoV-2/COVID-19 pandemic. Advances in Nutrition 12(3): 670-681.

21. Gasmi A, Tippairote T, Mujawdiya PK, Peana M, Menzel A, et al. (2021) The microbiota-mediated dietary and nutritional interventions for COVID-19. Clinical Immunology 226: 108725.

\section{ISSN: 2574-1241}

DOI: 10.26717/BJSTR.2022.41.006633

Sylvia Smart. Biomed J Sci \& Tech Res

This work is licensed under Creative Commons Attribution 4.0 License

Submission Link: https://biomedres.us/submit-manuscript.php
22. Brodin P (2021) Immune determinants of COVID-19 disease presentation and severity. Nature Medicine 27(1): 28-33.

23. (2022) World Health Organization (WHO). Nutrition advice for adults during the COVID-19 outbreak.

24. García Bayona L, Comstock LE (2018) Bacterial antagonism in hostassociated microbial communities. Science 361(6408).

25. Matricardi PM, Dal Negro RW, Nisini R (2020) The first, holistic immunological model of COVID-19: implications for prevention, diagnosis, and public health measures. Pediatric Allergy and Immunology 31(5): 454-470.

$\begin{array}{ll}\text { BIOMEDICAL } & \text { Assets of Publishing with us } \\ \text { RESEARCHES } & \text { - Global archiving of articles } \\ & \text { - Immediate, unrestricted online access } \\ & \text { - }\end{array}$

